\title{
ДО ОБҢРУНТУВАННЯ ПЕРЕЛІКУ НЕБЕЗПЕЧНИХ ВИСОКОТОКСИЧНИХ ХІМІЧНИХ РЕЧОВИН, ЯКІ ПІДЛЯГАЮТЬ ОСОБЛИВОМУ КОНТРОЛЮ ЩОДО ОБІГУ, ЗБЕРІГАННЯ, ВИКОРИСТАННЯ ТА УТИЛІЗАЦІї Частина 1 (рицин, сполуки талію та фосфорорганічні сполуки)
}

\author{
М.Г. Проданчук', Г.М. Балан', О.П. Кравчук', \\ П.Г. Жмінько ${ }^{1}$, І.М. Максимчук' ${ }^{2}$, Н.П. Чермних ${ }^{1}$ \\ 'ДП «Науковий центр превентивної токсикології, харчової та хімічної безпеки імені академіка \\ Л.І. Медведя МОЗ України», м Київ, Україна \\ ²Національна поліція України, м. Київ, Україна
}

\begin{abstract}
PЕЗЮМЕ. Мета роботи. На підставі аналітичного огляду літературних даних виділити групу високотоксичних хімічних речовин, котрі за останні десятиліття найчастіше використовуються в умисних кримінальних та суйиидальних інцидентах, диверсійних і терористичних актах, обіг, зберігання, використання та утилізацію яких потрібно особливо прискіпливо контролювати правоохоронним органам.

Матеріали та методи. Аналітичний огляд наукових публікацій виконаний з використанням реферативних баз даних наукових бібліотек Pub Med, Medline і текстових баз даних наукових видавництв Elsevier, Pub Med, Central, BMJ group та інших VIP-баз даних. Використано методи системного, порівняльного та контент-аналізу.

Результати та висновки. Проаналізовано наукові публікації щодо небезпечних високотоксичних хімічних речовин, які за останню чверть сторічия найчастіше використовуються у світі, зокрема в умисних кримінальних та суйцидальних інцидентах, диверсійних і терористичних актах. Установлено, що до них переважно відносяться: рицин, сполуки талію, фосфорорганічні сполуки та бойові отруйні речовини, мищ'як і його сполуки, ціаніди та неорганічні водорозчинні сполуки ртуті (сулема, мертіолят натрію), а також пестициди паракват і дикват. На основі аналізу їхньої токсичності, клінічних та морфологічних проявів інтоксикації за різних шляхів надходження до організму обгрунтовано необхідність внесення їх до Переліку особливо небезпечних хімічних речовин, обіг яких, зберігання, використання та утилізаиія потребують більш жорсткого контролю правоохоронних органів. У першій частині даної статті представлені рицин, сполуки талію, фосфорорганічні сполуки та бойові отруйні речовини.
\end{abstract}

Ключові слова: високотоксичні небезпечні хімічні речовини, рицин, сполуки талію, фосфорорганічні сполуки.

Важливим фактором суспільно-економічних відносин під час використання небезпечних хімічних речовин $є$ створення та функціонування механізмів стримувань i правового регулювання їхнього обігу, а також визначення заходів щодо покарання в разі порушення встановлених норм та правил.

У попередніх публікаціях ми зосереджували увагу на цій проблематиці, де більш детально було описано наслідки дерегуляціï законодавства під час поводження 3 отруйними речовинами [3], що виникла через активізацію євроінтеграційних процесів в Україні. Для поглиблення співробітництва 3 міжнародними організаціями щодо розвитку малого і середнього підприємництва та промисловості Україна взяла на себе зобов'язання стосовно приведення законодавства України у відповідність до вимог Директив Європейського Союзу, зокрема $з$ питань енергоефективності та чистого виробництва. У зв'язку із цим та 3 метою виконання Плану Урядом України прийнято постанову № 405 від 03 вересня 2014 року «Про визнання такими, що втратили чинність, деяких постанов Кабінету Міністрів України» [7], де серед інших і Постанова Кабінету Міністрів України від 20 червня 1995 року № 440 (далі Постанова № 440), якою затверджувався Порядок одержання дозволу на виробництво, зберігання, транспортування, використання, захоронення, знищення та утилізацію отруйних речовин, у тому числі продуктів біотехнології та інших біологічних агентів, до якого додавався Перелік отруйних речовин, у тому числі продуктів біотехнологій та інших біологічних агентів, виробництво, зберігання, транспорту- 
вання, використання, захоронення, знищення та утилізація яких здійснюються за наявності дозволу (далі - Перелік) [8].

Зазначений Перелік значно спрощував i юридично гарантував повноваження правоохоронних органів та експертних установ, які документували злочини, пов'язані 3 порушенням правил поводження 3 отруйними речовинами. Але після скасування Переліку, на жаль, значно зміцнилися позиції, пріоритети і переваги у діяльності адвокатів, які беруть участь у досудовому розслідуванні, а також у ході судового розгляду кримінальних проваджень, захищаючи осіб, що недбало поводяться або незаконно використовують отруйні речовини, які безперечно $є$ джерелом громадської небезпеки, загрозою здоров'ю i життю людини. Але, як не прикро, законодавчого визначення терміну щодо такої загрози у правовому полі не існує.

Водночас зазначена обставина практично ставить під сумнів правомірність діяльності органів досудового слідства щодо документування злочинів, пов'язаних 3 обігом отруйних речовин. Це дає бонуси стороні захисту підозрюваних. У разі доведення кримінального провадження до судового розгляду, що трапляється вкрай рідко, їня робота зводиться нанівець через відсутність судової перспективи, адже суспільно-економічні та правові відносини за даним напрямком невизначені та неврегульовані.

У даний час у Кабінеті Міністрів України розглядається «Перелік отруйних речовин, у тому числі продуктів біотехнологій та інших біологічних агентів» за №27421/10/1-18, до якого ввійшли 485 назв хімічних речовин та їхніх сполук. За ними обов'язково має бути відповідний нормативно-правовий контроль, зокрема на етапах ввезення до країни, як законного, так і протизаконного виробництва, виготовлення, пересилання, зберігання, транспортування, використання, знищення та утилізації відповідно до законодавства ЕС.

Поряд $з$ розширеним списком небезпечних хімічних речовин у кожній країні (в тому числі й на теренах пострадянських) є законодавчо затверджений перелік 67 високотоксичних небезпечних хімічних сполук, які за останні 25 років найчастіше використовуються у світі у кримінальних та суїцидальних інцидентах, диверсійних і терористичних актах, що потребують більш жорсткого нормативно-правового контролю. Небезпека полягає в тому, що ці особливо небезпечні хімічні речовини надходять до країни не стільки через митний кордон, скільки контрабандним шляхом $\mathrm{i}$ розповсюджуються за допомогою оголошень в інтернеті, часто виготовляються в нелегальних лабораторіях.

Аналіз зарубіжної та вітчизняної літератури показав, що останнім часом у кримінальних та суїцидальних інцидентах, диверсійних і терористичних актах використовуються переважно такі хімічні речовини: рицин, сполуки талію, фосфорорганічні сполуки (ФОС) та бойові отруйні речовини (БОВ), миш'як та його сполуки, ціаніди, пестициди паракват i дикват, а також ртуть та їі сполуки.

Мета роботи. На підставі аналітичного огляду літературних даних виділити групу високотоксичних небезпечних хімічних речовин, котрі за останні десятиліття у світі найчастіше використовуються у кримінальних та суїцидальних інцидентах, диверсійних і терористичних актах, обіг, зберігання, використання та утилізація котрих потребують особливо жорсткого контролю правоохоронних органів.

Матеріали та методи. Аналітичний огляд наукових публікацій виконаний з використанням реферативних баз даних наукових бібліотек Pub Med, Medline і текстових баз даних наукових видавництв Elsevier, Pub Med, Central, BMJ group та інших VIP-баз даних. Використано методи системного, порівняльного та контент-аналізу.

\section{Результати та висновки}

1. Рицин. Рицин міститься в насінні рицини (Ricinus communis, R. communis) i € одним 3 найбільш високотоксичних речовин. Рицина широко росте у тропічних регіонах і культивується 3 прадавніх часів для отримання касторової олії як послаблюючого засобу, пального для олійних ламп [9, 10]. У даний час рицина використовується в медицині для розробки протипухлинних лікарських засобів, при виробництві послаблюючого 3 касторової олії, а також для виготовлення косметики, фарб, мастил та інших промислових продуктів [9, 10, 11]. Основними виробниками 
касторових бобів є Китай, Індія, Бангладеш і США, де вони широко використовуються для отримання касторової олії. У самій олії рицину немає - технологія його отримання включає інактивацію токсину шляхом нагрівання.

Очищений рицин - це білий порошок без запаху, добре розчинний у воді, який зберігає токсичні властивості в широкому діапазоні $\mathrm{pH}$. У водних розчинах рицин інактивується при температурі $80^{\circ} \mathrm{C}$ протягом години, в сухому вигляді він більш стійкий $[10,11,12]$.

Молекулярна маса рицину - 60-65 кДа. Рицин, як і токсини холери та кашлюку, є бінарним токсином - належить до сімейства А-B, котре має два функціонально різні поліпептидні ланцюги А і В. Ланцюг A - це токсин рицину A або RTA, має молекулярну масу 32 кДА, а ланцюг В, відомий як токсин рицину В або RTB, має молекулярну масу 34 кДА [9, 10, 25]. Ланцюги А і В зв'язані дисульфідним зв'язком. Кількість рицинового токсину та його ізоформ залежить від сорту рицини, iі зрілості та умов вирощування. Найвідоміші ізоформи рицинового токсину включають аглютинін R. Communis (RCA), рицин D (RTD) і рицин Е (PTE). Аглютинін R. Communis зв'язується з еритроцитами і викликає їх аглютинацію і гемоліз $[9,10,11]$. Субодиниці рицину А і В як такі не токсичні, токсична дія проявляється лише при взаємодії обох субодиниць у складі молекули рицину. В-ланцюг - це лектин, що зв'язується 3 галактозою поверхні клітини-мішені, викликаючи ендоцитоз і проникнення молекули рицину у клітину $[9,10,11]$. 3 ранньої ендосоми В-ланцюг рицину сприяє проникненню і у транспортну мережу Гольджі (рис. 1) [11]. У свою чергу А-субодиниця рицину $\epsilon$ високоефективною $\mathrm{N}$-глікозидазою. Її дія спрямована на інактивацію специфічної аденінової основи (А4324) поблизу 3-кінця $28 \mathrm{~S}$ рибосомальної РНК. Одна А-субодиниця рицину здатна за хвилину інактивувати приблизно 1500 рибосом, внаслідок чого аміноацилтранспортна РНК не зв'язується з усіченою $28 \mathrm{~S}$ рибосомальною РНК, синтез білку у клітині зупиняється і запускається механізм передчасного апоптозу $[10,11,12,15]$, що обумовлює пряму цитотоксичну дію.

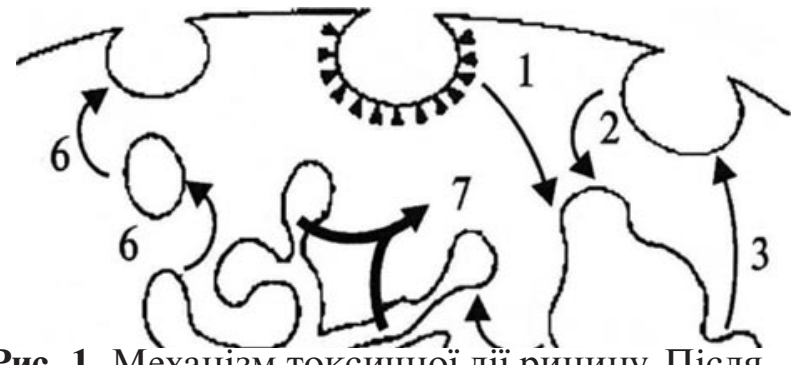

Рис. 1. Механізм токсичної діі рицину. Після взаємодії В-субодиниці рицину з галактозою або N-ацетилгалактозаміном на поверхні клітини, молекула токсину піддається ендоцитозу $(1,2)$. Більшість молекул рицину виводиться назад на поверхню клітини завдяки механізму екзоцитозу (3). Якщо везикули зливаються з лізосомами, то рицин руйнується завдяки механізму протеолізу (4). Частина везикул, що містять рицин, зливається 3 транспортною мережею Гольджі (trans-Golgi network, TGN) (5), звідти вони також можуть бути виведені на поверхню клітини (6).

Токсичну дію рицин проявляє тоді, коли його молекула розпадається на субодиниці, тоді Асубодиниця пенетрує мембрану TGN і проникає в цитозоль (7), де каталізує депуринізацію (depurination) рибосом, зупиняючи синтез білка. (Bigalke H, Rummel A, 2005) [11].

Летальні дози рицину залежать від способу введення в організм тварини, від виду тварини, ступеня очистки рицину, умов його зберігання і наявності ізоформ у препараті. LD $_{50}$ дрібнодисперсного аерозолю очищеного рицину (розмір частинок аерозолю 1-5 мкм) для щурів у межах 4,5412,7 мг хв/ $\mathrm{m}^{3}\left(\mathrm{LD}_{50} 3,7-9,8\right.$ мкг/кг) [13, 14]. Летальні дози рицину при інгаляційному ураженні для мавп-резусів та африканських зелених мавп становили 15,0 i 5,8 мкг/кг [14]. Мінімальна інгаляційна летальна доза дрібнодисперсного аерозолю рицину для людини - близько 4 мКг/Кг $[14,26]$. При ентеральному отруєнні для людини $\mathrm{LD}_{50}$ рицину становить 1$20 \mathrm{Mг/кг} \mathrm{[10,} \mathrm{11,} \mathrm{12].} \mathrm{Зниження} \mathrm{токсичності}$ рицину при потраплянні в організм через шлунково-кишковий тракт обумовлене його інактивацією шлунковим соком i панкреатичними ферментами. Симптоми отруєння і причина смерті залежать від місця аплікації токсину [9-22]. Клінічні та параклінічні прояви токсичності рицину у тварин залежать від шляху введення. 
Внутрішньом'язові ін'єкції викликають сильний локалізований біль, ущільнення тканин у місці ін'єкції з некрозом м'язів і регіонарних лімфатичних вузлів 3 подальшим формуванням системних уражень залежно від дози. За великих доз формується ураження печінки, нирок, шлунково-кишкового тракту, серцево-судинної системи з розвитком колапсу та смерті [9, 10,15-17].

Інгаляційна дія рицину викликає у тварин (миші, кролики, примати) формування респіраторного дистрес-синдрому 3 ураженням бронхів і легень 3 вираженою задишкою. При високих дозах формується некардіальний набряк легень і смерть внаслідок гіпоксемії протягом декількох годин. [10, 11, 13, 14, 19]. Патоморфологічна картина характеризується вираженою проникністю судин, периваскулярним набряком легень, заповненням альвеол ексудатом з високим вмістом прозапальних цитокінів і гіалуронідази. Крім того, спостерігається виражене порушення мікроциркуляції та тромбоутворення. Уже через декілька годин після інгаляції рицину у тварин з'являється збільшення екстраваскулярної рідини в легенях і альвеолярний набряк. Імунохімічні дослідження показали, що інгальований рицин зв'язується з війчастими клітинами, альвеолярними макрофагами та альвеолярними обкладувальними клітинами дихальних шляхів [27], причому неочищений рицин викликає більші та різноманітніші порушення $[9,10,13,14]$. Інгаляційна дія рицину на нелюдиноподібних приматах показала, що його інгаляційна токсичність має дозозалежний преклінічний період 2-24 години. У клінічному періоді у тварин спостерігається задишка, прогресуюче зниження рухової активності та анорексія. Через 6-48 годин після інгаляції рицину тварини гинули від легеневої та легеневосерцевої недостатності. Швидкість загибелі тварин також залежала від інгальованої дози. Патоморфологічно в загиблих мавп виявлено гнійно-фібринозну пневмонію, легені не колапсовані, але важкі, щільної пружної консистенції, покриті рідиною. Вісцеральна легенева плевра покрита плівкою фібрину. У плевральній порожнині серозна рідина з нитками фібрину. На поверхні легень спостерігалися масивні геморагії та некротичні зміни. Морфологічно в легеневій тканині мав місце гнійно фіброзний альвеоліт $з$ інфільтрацією нейтрофілами, лімфоцитами та макрофагами. Термінальні бронхіоли некротизовані та «роздуті» міграцією еозинофілів, еритроцитів, макрофагів і відкладенням ниток фібрину. У ряді мавп виявлений адренокортикальний некроз.

При пероральному введенні рицину у тварин були дозозалежні геморагічні та некротичні порушення у шлунково-кишковому тракті, токсичне ураження печінки, нирок, селезінки. Гинуть тварини за високих доз протягом 12-48 годин від печінково-ниркової недостатності. Патоморфологічно - множинні геморагії та вогнища некрозу у шлунково-кишковому тракті, брижі, печінці, нирках, лімфовузлах та асцит.

Гострі отруєння рицином у людини, в тому числі й насінням рицини, були достатньо поширені в минулому столітті описано більше 1000 випадків навмисних і суїцидальних отруєнь [9-28], але і в останні десятиліття вони також реєструються. Клінічна картина інтоксикації рицином це прояви місцевої та резорбтивної дії, в основі яких лежать цитотоксичний і цитостатичний ефекти, порушення процесів метаболізму у клітинах, у які проникає ця речовина $[9,10,11,28]$. Клінічні прояви інтоксикації залежать насамперед від дози рицину і шляху потрапляння в організм, його розрахункова смертельна доза для людини при прийомі через рот становить приблизно 0,3 мг/кг (біля 20 мг). При інгаляції дрібнодисперсного аерозолю його токсичність значно вища - мінімальна інгаляційна летальна доза рицину для людини близька до 40 мкг/кг. Через неушкоджену шкіру рицин токсично не діє [9-16, 23, 24, 27, 28]. Рицин легко проникає при інгаляційному надходженні через клітини альвеолярно-капілярного бар'єру бронхо-легеневої системи, дещо менше через слизову оболонку шлунково-кишкового тракту при пероральному надходженні. Потрапивши у кров, речовина розподіляється в організмі, швидко фіксується на поверхні еритроцитів, клітин ендотелію різних органів і тканин. Протягом декількох годин після вживання $з$ їжею рицину або насіння рицини (касторових бобів) в 
отруєного з'являються нудота, блювання, біль у черевній порожнині, напади кишкової коліки, потім профузний пронос 3 кров’ю, нерідко - кровотеча з ануса. До цих проявів приєднуються анурія, судоми, розширення зіниць, підвищення температури тіла до $40-41^{\circ} \mathrm{C}$, головний біль, посилене відчуття спраги, ціаноз шкірних покривів. До них приєднуються жовтяниця, анурія, судинний колапс і шок. Смерть настає через декілька годин при високих дозах, але частіше - через 2-4 доби [9-16, 27, 28].

У літературі описано вбивство в Лондоні в 1978 році болгарського дисидента Георгія Маркова. Імовірно шляхом уколу у стегно парасолькою в нього була випущена 1,7 мм куля, що містила приблизно 500 мкг рицину. Марков майже відразу відчув локальний біль у стегні, в ділянці, в яку потрапила куля. Через 10-15 годин у нього різко підвищилася температура, з'явилися нудота і блювання. На другу добу після пострілу він був доставлений у госпіталь у важкому стані з високою температурою, тахікардією, зі збільшеними болючими лімфовузлами, з блюванням з кров’ю. На третю добу з'явився лейкоцитоз до $32200 / \mathrm{Mm}^{3}$, жовтуха, анурія, судинний колапс, тахікардія, на ЕКГ виявлено повну атріовентрикулярну блокаду. Під кінець третьої доби Марков помер [9, 10, 29].

Запідозрити отруєння рицином можна на основі клінічних ознак: нудота, біль у животі, кривавий пронос, дисемінована внутрішньо-судинна коагуляція 3 формуванням гепатоцелюлярної, ренальної та серцево-судинної недостатності. Ураження аерозолем рицину можна припускати у випадку: 1) появи через декілька годин у хворих геморагічних явищ у сітківці очей, ознак прогресуючої легеневої патології задишки, кровохаркання, виявлення на рентгенограмах двосторонніх великих інфільтратів, плевриту, наростаючого набряку легень; 2) виявлення на секції патології внаслідок дії дрібнодисперсного аерозолю; 3) встановлення епідеміології точкового джерела локалізованого вогнища ураження $[9,10,25,30]$. Підтвердити факт рицинової інтоксикації, принаймні через 24 години після інциденту, можливо імуноферментним методом. Чутливість ELISA по рицину - 1 нг/мл при визначенні токсину в буферному розчині, у змиві бронхів, сироватці крові та сечі [31].

Через високу токсичність і простоту виготовлення воєнний депаратамент США ще в 1918 році розглянув рицин як потенційну зброю і назвав іiі «сполука W». У Британії та США було розроблено «W бомбу» і випробувано під час Другої світової війни, але вона офіційно ніколи не використовувалася [9, 32]. Автори повідомляють також про недавні спроби замахів на життя президентів США і сенатора шляхом пересилання конвертів, що містили порошок рицину $[9,32,33]$.

Ризик біотероризму при використанні такої високотоксичної речовини як рицин зберігається, а ефективні засоби лікування до сьогодні відсутні, токсин діє швидко і безповоротно. Тому, вакцинація груп високого ризику як превентивний захід є важливою захисною стратегією [9, 10, 26-28, 32]. Розроблені ефективні вакцини, що містять антирицинові моноклональні антитіла $[9,10,25-28,32-36]$. В останні роки, враховуючи потужну цитотоксичну та цитостатичну дію рицину, модифікований його токсин використовується для розробки хіміотерапевтичних засобів для лікування раку. Слід також відзначити, що в розвинутих країнах обіг, зберігання та використання такої високотоксичної небезпечної речовини як рицин підлягає особливому контролю.

2. Талій $і$ його сполуки. Талій (Tl) та його сполуки $\left(\mathrm{Tl}^{+}\right)$до сьогоднішнього дня широко використовують у різних галузях промисловості. Так, в електротехнічній галузі - при виготовленні селенових випрямлячів, градуюваних спектральних приладів, виробництві безелектродних розрядних ламп. В атомній промисловості $\mathrm{Tl}^{+}$використовуються як активатор люмінесцентних лужно-галоїдних кристалів, у сцинтиляційних лічильниках. Сплави $\mathrm{Tl}$ мають високі антифрикційні властивості та велику корозійну стійкість. $\mathrm{Tl}^{+}$використовуються в геології при вирощуванні кристалів, а також мурашино-малоновий кислий Tl входить до складу спеціального реактиву - «рідини Клеричі», яка застосовується в геології для визначення наявності кольорових металів [37-41].

У приладобудуванні окремі $\mathrm{Tl}^{+}$використовуються як джерело $\beta$-випромінювання. $\mathrm{Tl}^{+}$активно застосовуються у вироб- 
ництві оптичних лінз та інших оптичних елементів, а також нових напівпровідникових матеріалів 3 мінливими властивостями щодо їхньої провідності та у виробництві фарб і біжутерії. До 70-85-х років сполуки Tl широко використовувалися в різних країнах, зокрема і в Україні, в сільському господарстві в якості родентицидів, інсектицидів при протравлюванні зерна (насіннєвого фонду), в дерматології у складі засобів для епіляції при лікуванні мікозів волосяної частини голови [37-43].

Уперше талій був виявлений у 1861 році. Уільям Крукс під час спалювання пилу на промисловому підприємстві по виробництву сірчаної кислоти помітив яскраво-зелену спектральну смугу, що швидко зникала. Новий елемент був названий талієм (від грецького - «талос» зелений пагін) [37].

Основні сполуки талію - це талію сульфат, талію ацетат, талій йодистий, талій бромистий, талію окис, талію гідроокис, талію фторид, талію карбонат, талію малонат, талію нітрат. Більшість сполук Tl відноситься до високотоксичних речовин I класу небезпеки. Ступінь їхньої токсичності наростає в міру підвищення розчинності у воді. Розчинні солі Tl всмоктуються як при прийомі всередину (протягом 23 годин), так і при парентеральному введенні, через інтактну шкіру та бронхолегеневу систему при інгаляційному надходженні. При цьому добре розчинні солі $\mathrm{Tl}^{+}$(сульфат, ацетат, карбонат) швидше всмоктуються в кишечнику, ніж менш розчинні (сульфід і йодид). Після перорального надходження сульфату талію він може бути виявлений у калі та сечі вже через одну годину. У ранні терміни більші концентрації Tl виявляються в печінці, нирках, головному мозку, периферичних нервах, серці, яєчках [45]. В організмі людини i тварин $\mathrm{Tl}^{+}$виводиться переважно нирками з сечею (до 70\%) і калом, а також зі слиною, потом, сльозами та грудним молоком [46]. Період напіввиведення 3 організму людини залежить від дози $\mathrm{Tl}^{+}$, віку, функції нирок і коливається від 4-х до 30 днів, а підвищена концентрація може спостерігатися і кілька місяців $[45,46]$.

Смертельна доза для людини становить 10-15 мг розчинної солі Tl на 1 кг маси тіла (біля 1 г для людини вагою 70 кг). Проте смерть може настати і при більш низьких дозах (9-8 мг/кг) [52]. У крові вміст Tl в нормі не повинен перевищувати 2 мкг/л, у сечі - від 1,5 до 10 і навіть 200 мкг/л за даними різних авторів [37-42, 47, 48, 51].

Високотоксичні сполуки $\mathrm{Tl}^{+}$ще 3 початку XX століття - це одна з основних причин поодиноких і групових випадкових, навмисних і суїцидальних гострих отруєнь, котрі в 15-25\% випадків донині закінчуються летальним результатом [37-43, 44 52]. Через широке їх застосування в сільському господарстві, медицині, косметології та в інших галузях промисловості ці сполуки були достатньо доступні. Але через високу токсичність і потенційний ризик для здоров'я сполуки $\mathrm{Tl}\left(\mathrm{Tl}^{+}\right)$ 3 7585 років були заборонені або значно обмежені для використання в сільському господарстві, а також у медичній сфері в більшості розвинутих країн, зокрема і у країнах пострадянського простору, що сприяло деякому спаду числа гострих отруєнь. Але слід відзначити, що в більшості країн південної Азії збереглося виробництво та використання високотоксичних сполук $\mathrm{Tl}^{+}$в сільському господарстві в якості інсектицидів і особливо родентицидів [3739]. У зв'язку з розширенням мережі інтернету у двохтисячних роках і особливо за останні 20 років доступність сполук $\mathrm{Tl}$ i поширення гострих отруєнь $\mathrm{Tl}^{+}[37-42,45$, $46,52-61,68-71]$ знову зросли в усіх країнах, зокрема і в Україні $[48,50]$. Це стало можливим у зв'язку з розміщенням оголошень про роздрібну та оптову торгівлю $\mathrm{Tl}^{+}$ з Китаю та інших країн в мережі інтернету, що знову підвищило його доступність [48, 50]. У ряді країн почастішали як поодинокі, так і групові випадки умисних (кримінальних), випадкових і суїцидальних гострих отруєнь сполуками $\mathrm{Tl}$ [38-42, 45, 48-61, 68-71]. Так, Г.А. Ліванов і співавт. [61] описують гострі пероральні групові тяжкі отруєння $\mathrm{Tl}^{+}$у Росії в Ярославлі (14 чоловік), Москві (8 осіб), СанктПетербурзі (5 осіб) кримінального характеру. Л.Б. Завалій і співавт. [39] описують 44 випадки перорального гострого отруєння $\mathrm{Tl}^{+}$на заводі в Таганрозі, при цьому припушено кримінальний пероральний шлях потрапляння $\mathrm{Tl}^{+} 3$ питною водою 3 офісного кулера. Описані випадкові та умисні отруєння $\mathrm{Tl}^{+}$при вживані наркотичних засобів в Ірані, особливо тих, що 
містять опій, які потрапляють 3 Афганістану, коли для збільшення ваги або умисно до наркотичних засобів додаються сполуки талію або свинцю [78, 79].

Почастішання в Україні за останні роки розвитку як поодиноких, так і групових випадків гострих пероральних та інгаляційних отруєнь $\mathrm{Tl}^{+}$випадкового та кримінального характеру описано нами в попередніх номерах журналу [48, 50, 64-67]. Увагу було зосереджено на сучасних уявленнях про механізми токсичної дії $\mathrm{Tl}^{+}$, клініці, діагностиці гострих отруєнь, динаміці вмісту талію в біосередовищах (крові, сечі, волоссі і нігтях) хворих з пероральними та інгаляційними гострими отруєннями сполуками талію, що знаходилися під нашим спостереженням. Показано, що в Україні за останні роки почастішала поява i розвиток гострих пероральних отруєнь $\mathrm{Tl}^{+}$, у тому числі тяжкої форми, а також зафіксовано незвичайний груповий випадок гострого інгаляційного отруєння парами сульфату талію.

Найвідомішим випадком групового перорального отруєння $\mathrm{Tl}^{+}$була кримінальна пригода в березні 1987 року в одній із київських шкіл, де посудомийка Іванютина Тамара через особисту неприязнь вирішила отруїти кухаря і в їжу, що залишилася після обіду, додала рідину Клерічі (найбільш високотоксична сполука талію). Цю трагічну історію широко висвітлено в пресі і на телебаченні [64-67], на одному з телеканалів демонструвався документальний серіал «Отруйна школа» [67]. На біду, пізніше до їдальні прийшли 13 осіб (школярі та кілька педагогів), яких нагодували отруєним обідом. За кілька годин у всіх почалися блювання, інтенсивні болі в животі, діарея, озноб, підвищення температури, болі в м'язах кінцівок. Хворих 3 підозрою на харчову інтоксикацію госпіталізовано до реанімаційного відділення. Симптоми при госпіталізації - збудження, гіперемія обличчя, лихоманка, нудота, блювання, інтенсивні болі в животі, діарея, генералізовані болі в м'язах, болісні хворобливі парестезії в кистях і стопах, судоми. Двоє школярів і двоє педагогів померли в першу добу від наростаючої легенево-серцевої недостатності, інші 9 осіб продовжували лікування з приводу харчової токсикоінфекції в реанімації. На
4-8 день почалося інтенсивне випадіння волосся, було запідозрено отруєння $\mathrm{Tl}^{+}$, вміст $\mathrm{Tl}^{+}$в сироватці крові у 9 обстежених коливався від 4660 до 22840 мкг/л. Отруєння $\mathrm{Tl}^{+}$підтверджено під час ексгумації і у дієтсестри цієї школи, яка померла за два тижні до даного інциденту, нібито від серцево-судинної патології. Слідством встановлено, що за 11 років Іванютина 3 сестрою отруїла $\mathrm{Tl}^{+} 40$ осіб, з них 13 - зі смертельними наслідками (була засуджена до смертної кари) [64-67].

За останні роки нами спостерігалися 3 випадки пероральних отруєнь $\mathrm{Tl}^{+}$у тяжкій формі, з них 2 - кримінального характеру і 1 - внаслідок випадкового вживання розчину сульфату талію, приготованого нібито для дератизації. У всіх трьох випадках захворювання почалося з болю в животі, нудоти, блювання, проносу, лихоманки, інтенсивних м'язових болів у кінцівках, болісних парестезій в кистях і стопах, судом у кінцівках. Через 5-8 днів у всіх трьох постраждалих з'явилася алопеція, переважно в тім'яно-потиличній області, піодермія обличчя, тріщини в кутах рота, гіперкератоз у ділянці кистей і стоп, слабкість у кінцівках. Через 8-10 днів з'явилася дизартрія, атаксія, млявий парез верхніх і особливо нижніх кінцівок, зниження активності сухожильних рефлексів рук, зникнення колінних, ахіллових і черевних рефлексів. У двох з них відзначалося зниження гостроти зору, порушення мови. В усіх трьох випадках з'явилася виражена гіпотрофія м'язів гомілок, стегон, плечей і передпліч, порушення функції тазових органів. У двох хворих визначення $\mathrm{Tl}$ в сечі було виконано через 10-14 днів після початку захворювання і становило 2840 i 2160 мкг/л відповідно. У третього хворого інтоксикацію $\mathrm{Tl}^{+}$запідозрили лише через місяць, вміст $\mathrm{Tl}$ в сечі в цей період становив 1425 мкг/л. У перших двох хворих неврологічна симптоматика протягом 1-го року наростала, потім стабілізувалася зі збереженням енцефаломієлополірадикулоневропатії зі слабкістю в руках і млявим парезом нижніх кінцівок, 3 вираженою атаксією і здатністю пересуватися тільки в колясці протягом 3-х років спостереження. Проведення комплексної терапії 3 включенням антидоту фероцину сприяло зниженню вмісту T1 в сечі до 100- 
120 мкг/л. Протягом місяця регресу неврологічних розладів не спостерігалося, прогресували зниження зору, депресія, когнітивні порушення, зберігалися порушення функції тазових органів. Після вираженої алопеції через 4-6 місяців у всіх трьох випадках виросло густе волосся. У третього хворого неврологічна симптоматика наростала до 6-8 місяців, потім після тривалої реабілітації дещо зменшилася. При контролі через 1 рік - зберігалися млявий парез нижніх кінцівок, атаксія, але хворий став пересуватися за допомогою милиць. Всім трьом хворим визначено I групу інвалідності. При проведенні ЕНМГ виявлено ознаки вираженої моторно-сенсорної поліневропатії аксонального характеру. Слід зазначити, що першим двом хворим, яким талотоксикоз встановлено через 10-14 днів, i своєчасно проведено антидототерапію фероцином, виявлено зниження рівня $\mathrm{Tl}^{+}$в сечі, але регресу неврологічної симптоматики практично не відбулося. У третього хворого талотоксикоз встановлено лише через місяць, а до цього він лікувався в різних клініках Києва $з$ діагнозом «поліневропатія неясної етіології» 3 призначенням гормонів, антибіотиків і плазмоферезу (№ 5). Антидот фероцин йому був призначений через місяць, коли $\mathrm{Tl}^{+}$у сечі становив 1425 мкг/л, після лікування з включенням фероцину $\mathrm{Tl}^{+}$у сечі знизився до 116 мкг/л, через рік хворий став пересуватися за допомогою милиць. Якщо через місяць рівень $\mathrm{Tl}^{+}$у сечі був 1425 мкг/л, то можна припустити, що в гострий період його рівень був значно вищим. Крім того, специфічну терапію він отримав через місяць, проте регрес неврологічних розладів у нього був більш помітним у порівнянні з двома першими випадками.

Особливий інтерес представляють три випадки розвитку гострого інгаляційного отруєння парами $\mathrm{Tl}^{+}$у водіїв легкового автомобіля. Їхня машина ремонтувалася у дворі приватної особи, котра мала кількох собак, які заважали жити сусідам. Ймовірно, хтось із них вирішив знищити собак і накидав отруєної каші через паркан. Каша потрапила на автомобіль і через відкритий капот - на двигун. Господар витер машину від каші зовні, i на ній почав працювати його двадцятитрьохрічний син. Через 1,5-2 доби у нього з'явилося інтен- сивне відчуття печіння в горлі, по ходу трахеї, за грудиною, в області діафрагми, утруднене дихання, інтенсивні болі в м'язах кінцівок, періартикулярних тканинах, болісні парестезії в пальцях кистей i стоп, болі в животі, різка слабкість у ногах. Спочатку хворий лікувався з підозрою на нейроінфекцію, після появи алопеції лабораторно було підтверджене гостре отру$\epsilon \mathrm{Hня} \mathrm{Tl}^{+}$і потерпілого перевели до лікарні швидкої медичної допомоги (ЛШМД). При наростанні легенево-серцевої недостатності хворий помер наприкінці літа 2018 року з діагнозом гостре отруєння $\mathrm{Tl}^{+}$, однак зв'язок розвитку інтоксикації 3 водінням автомобіля не був встановлений. Після смерті юнака на даному автомобілі періодично стали працювати його 42-річний батько і 48-річний напарник. У листопаді 2018 р. при настанні холодів вони почали включати кондиціонер для нагрівання салону автомобіля, після чого відчули печіння в горлі, по ходу трахеї, за грудиною, потім у обох з'явилися інтенсивні болі в м'язах, парестезії в пальцях кистей і стоп, слабкість у ногах, почала розвиватися алопеція. Батько померлого юнака поступив до токсикологічного відділення ЛШМД Києва восени 2018 р., де лікувався протягом 1,5 місяця 3 діагнозом гостре отруєння солями $\mathrm{Tl}^{+}$, синдром енцефалополірадикулоневропатії II-III ст., токсичний гепатит I-II ст. Через тиждень з аналогічними скаргами до цього ж відділення поступив його напарник по роботі на даному автомобілі, який знаходився на лікуванні протягом 20 днів 3 діагнозом гостре отруєння солями талію, синдром полірадикулоневропатії II ст., токсичний гепатит I-II ст. В обох хворих при обстеженні в нашому Науковому центрі рівень $\mathrm{Tl}^{+}$у волоссі був більше ніж у 10 разів вищим за норму, а в сечі - 320-280 мкг/л. Після комплексної детоксикаційної терапії з проведенням гемодіалізу, курсу антидотної терапії фероцином, ноотропів, анальгетиків, антиконвульсантів, антиоксидантів, вітамінів групи В, РР стан хворих покращився, відзначався істотний регрес неврологічних розладів, зникли болі за грудиною, м'язові болі, припинилося випадіння волосся. Хіміко-токсикологічна оцінка вмісту $\mathrm{Tl}^{+}$у волоссі і нігтях хворих, проведена в нашому Науковому 
центрі через 2,5 місяці після гострого отруєння, виявила вміст $\mathrm{Tl}^{+}$у одного хворого у волоссі - 800 мкг/кг, у нігтях - 2230 мКг/Кг, в епітелії шкіри - 190 мкг/кг. В іншого хворого з більш вираженими неврологічними порушеннями рівні $\mathrm{Tl}^{+}$були вищими: у волоссі - 3980 мКг/Кг, у нігтях - 9080 мКг/КГ, в епітелії шкіри - 620 мкг/кг, що свідчить про певну залежність вираженості клінічних проявів від вмісту $\mathrm{Tl}^{+}$у біосередовищах, переважно в сечі і нігтях. Слід зазначити, що через 2,5 місяця після отруєння найвищі рівні $\mathrm{Tl}^{+}$були у волоссі $\mathrm{i}$ особливо нігтях пацієнтів. Через рік - зберігалися периферична поліневропатія, легка атаксія, тремор пальців витягнутих рук, гіпорефлексія, депресія.

Хіміко-токсикологічну оцінку поверхонь салону машини, на якій працювали всі троє постраждалих, на жаль, проведено в Науковому центрі тільки через півроку після виникнення першого з трьох випадків гострого отруєння $\mathrm{Tl}^{+}$. Зроблено екстракцію 5\% $\mathrm{HCl}$ зрізів штучної шкіри 3 передніх сидінь і килимків, що лежали на підлозі салону. У 3-х пробах, взятих 3 сидінь через півроку, виявлено досить високі концентрації $\mathrm{Tl}^{+}$- до 68060 мкг на 30 мл екстракту (або 2269 мкг/мл). У пробах з килимків, що лежали на підлозі салону, концентрації $\mathrm{Tl}^{+}$в екстрактах були трохи нижчими. 3 огляду на забруднення салону машини $\mathrm{Tl}^{+}$, яке півроку тому, мабуть, було більш вираженим, гостре отруєння $\mathrm{Tl}^{+}$, ймовірно, виникло інгаляційним шляхом, причому клінічні прояви у двох останніх хворих з'явилися вже при настанні холодів, на початку листопада, коли вікна машини закривалися і включався підігрів салону. Слід зазначити, що в Науковому центрі проведено дослідження вмісту $\mathrm{Tl}^{+}$у біопробах ексгумованого трупа чоловіка, який помер у 2019 р. від неврологічної патології неясної етіології (за наполяганням родичів, що підозрювали отруєння). У біопсованій ділянці шкіри ексгумованого трупа рівень $\mathrm{Tl}^{+}$досягав 8000 мкг/кг, а в зрізаних нігтях - 9000 мкг/кг, що дозволило встановити, що причиною його смерті також було отруєння $\mathrm{Tl}^{+}$.

Описані випадки інтоксикації $\mathrm{Tl}^{+}$свідчать про те, що доступність придбання його сполук в інтернеті сприяє зростанню гострих отруєнь серед населення, крім того, не можна виключити, що в багатьох випадках хворі загинули до встановлення точного діагнозу.

Почастішали групові отруєння $\mathrm{Tl}^{+}$кримінального характеру і в Японії [72, 73, 77], Китаї [58, 62, 64, 75, 76] та багатьох інших країнах [40-46, 52, 55, 58-60]. У ряді робіт описані терористичні інциденти групових гострих отруєнь, пов'язаних зі споживанням забруднених $\mathrm{Tl}^{+}$продуктів харчування - алкоголю в Іраку [59], солодощів в Сирії [60].

Механізм токсичної дії $\mathrm{Tl}^{+}$узагальнений нами в попередніх номерах журналу $[48,50]$. В основі токсичності $\mathrm{Tl}^{+}$лежить іонна схожість з калієм, причому сполуки талію майже в 10 разів активніші за калій, тому вони заміщують калій і конкурують 3 ним за місце в мітохондріальних та інших клітинних мембранах, численних ферментах, взаємодіють $3 \mathrm{Na}^{+} / \mathrm{K}^{+}-\mathrm{AT} Ф$-азою, викликаючи енергетичний дефіцит та активацію перекисного окиснення ліпідів. Цим процесам сприяють блокада SH-груп, наростання концентрації внутрішньоклітинного кальцію, наростання глютаматергічного компоненту в $\mathrm{Tl}^{+}$-індукованій токсичності у структурах головного мозку, а також підвищення збудливості нервових клітин з формуванням у них дегенеративних порушень.

Одночасно формується рибофлавінова недостатність, яка поряд з високою спорідненістю $\mathrm{Tl}^{+}$до меланіну порушує процес епідермальної кератинізації, пригнічує клітинну проліферацію, особливо фолікулярних меланоцитів і спричиняє розвиток одного із специфічних для отруєнь $\mathrm{Tl}^{+}$ синдромів - алопеції.

Клінічні прояви отруєння $\mathrm{Tl}^{+}$у перші години та дні досить неспецифічні, однак поєднання ряду симптомів і синдромів, а також послідовність їх розвитку має змусити лікаря запідозрити гостре отруєння даною небезпечною речовиною і почати проведення хіміко-токсикологічного обстеження. Послідовність розвитку основних симптомів інтоксикації $\mathrm{Tl}^{+}$обгрунтовано нами в попередніх номерах журналу [48, 50]:

- у перші години отруєння $\mathrm{Tl}^{+}$найчастіше спостерігаються гастроінтестинальні розлади, що супроводжуються інтенсивним болем у животі, нерідко кишковою колікою, як при інтоксикації свинцем, 
нудотою, блюванням, діареєю, анорексією, що імітує картину харчового отруєння, рідше спостерігаються закрепи, здуття живота. Однак слід звернути увагу, що ці шлунково-кишкові розлади передують або поєднуються з болісними парестезіями в пальцях кистей і стоп, інтенсивними розпираючими болями в підошвах стоп, судомами, наростаючим тремором, при великих дозах - психічними розладами, порушенням сну, головним болем, ураженням черепно-мозкових нервів зі зниженням корнеальних і глоткових рефлексів, а також підвищенням температури тіла до $37,6-38^{\circ} \mathrm{C}$; окрім того, в перші години, особливо за дії великих доз, сеча набуває зеленуватого забарвлення;

- на 2-10 день прогресують неврологічні порушення, наростає тремор, атаксія, посилюються болі в кінцівках, особливо в ділянці литкових м'язів і м'язів внутрішньої поверхні стегна, набуваючи ознак нейропатичних, з'являються м'язові атрофіï, переважно в області верхнього плечового пояса, гомілок і стегон, наростають розлади функції черепно-мозкових нервів, можливі параліч лицьового нерва, птоз, диплопія, ретробульбарний неврит, порушення зору. Якщо в перші 2-3 дні сухожилкові рефлекси зберігаються, то пізніше вони зникають, при великих дозах з'являються в'ялий параліч, тетрапарез, розлади функції тазових органів, а також приєднуються порушення функції серця, нирок, нерідко наступає смерть від серцево-дихальної недостатності;

- через 7-14 днів у хворих, які залишилися живими, з'являється алопеція, переважно в тім'яній і скроневих ділянках голови (рис. 2), також зникає волосяний покрив у пахвовій і лобковій ділянці, медіальній і латеральній третині брів, має місце лущення шкіри, гіперкератоз долонь і підошов, тріщини у кутках рота, коричнева пігментація, відкладення темного пігменту на шкірі навколо волосяних цибулин, розвивається піодермія (гнійничкові висипи і дрібні фурункули, особливо на обличчі, рідше на грудях і спині), різко сповільнюється ріст нігтів, вони тьмяніють, жовтіють, з'являється горизонтальна звивистість з білими поперечними смугами (смуг Меєса, рис. 3).

На жаль, у більшості описаних випадків
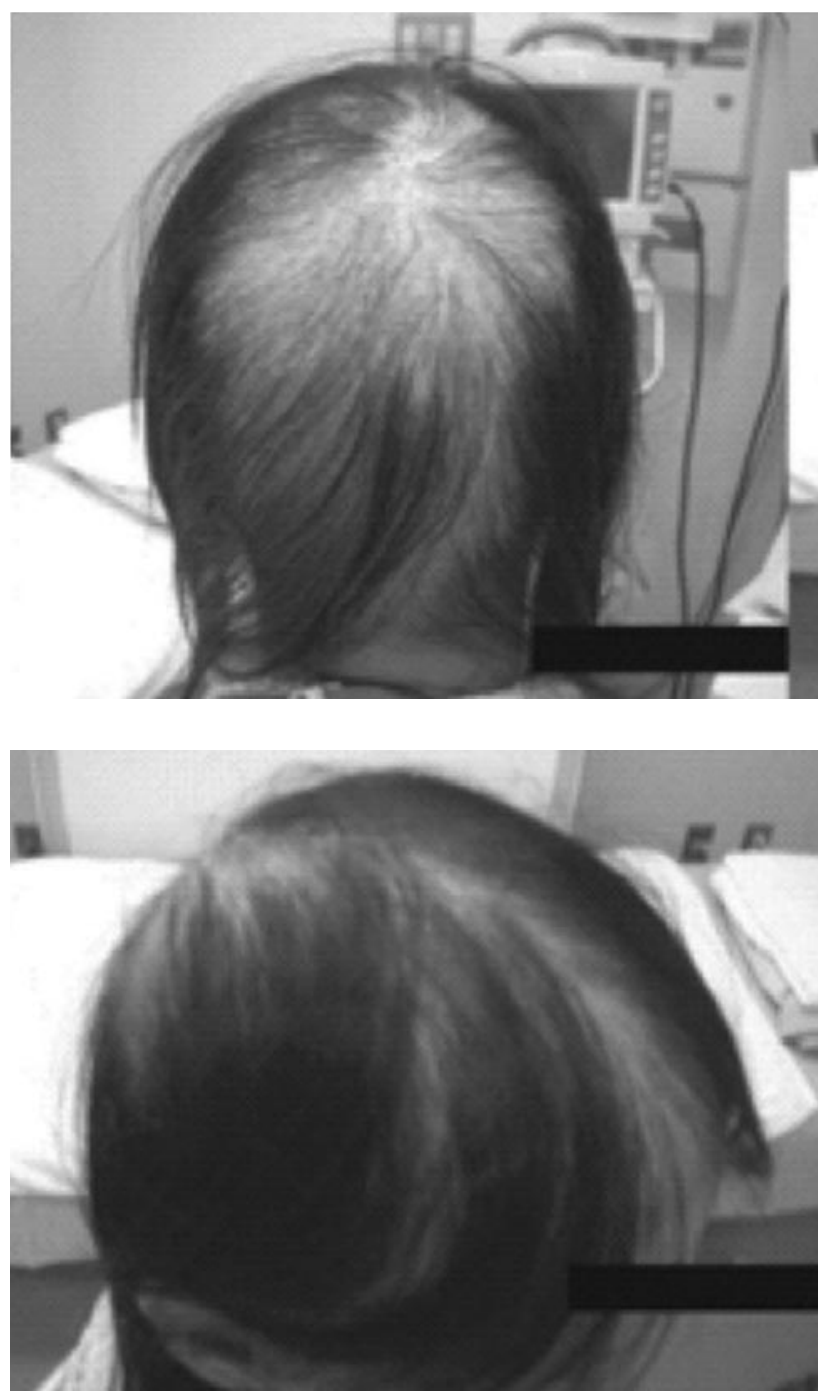

Рис. 2. Алопеція волосяної частини голови у хворої на гостре отруєння талієм (Yumoto T et al, 2017) [69]

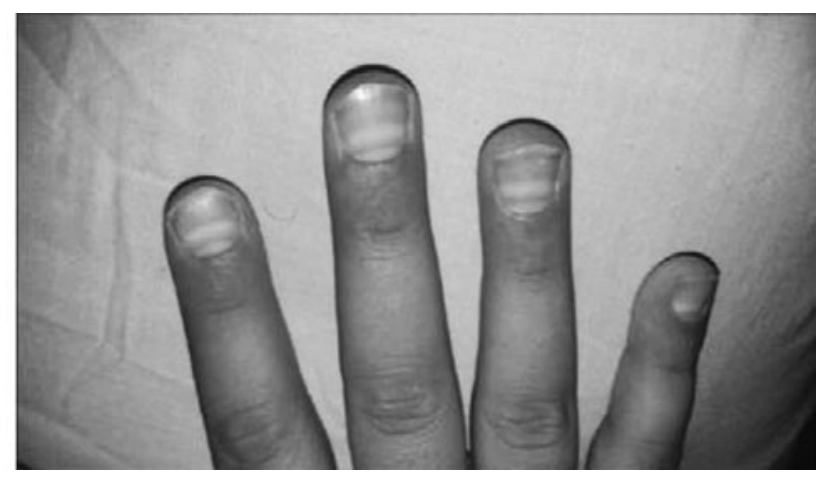

Рис. 3. Ураження нігтів з формуванням поперечних смуг Меєса у хворого на гостре отруєння талієм (Almassri I, Sekkarie M, 2018) [60]

гострих отруєнь $\mathrm{Tl}^{+}$діагноз встановлюється пізно, найчастіше через 1-2 тижні, коли з'являється алопеція, нерідко і через півтора-два місяці. Через це відтерміновується 
призначення антидоту фероцину (берлінської лазурі) і екстракорпоральної детоксикації, як наслідок формуються грубі порушення з боку центральної та периферичної нервової системи з розвитком парезів і паралічів, що призводить до інвалідизації. У даній роботі не розглядається випадок хімічної екзогенної інтоксикації в Чернівцях 1988 року, найвірогіднішою причиною якої могло бути потрапляння талію в організм інгаляційним шляхом в ультрамікродисперсному (нано-) стані.

Враховуючи представлені літературні дані та результати власних досліджень високої токсичності сполук талію, їх доступність через мережу інтернет, несвоєчасне встановлення точного діагнозу i часту інвалідизацію або летальний результат при розвиткові гострих отруєнь обгрунтовано потребу особливого контролю за обігом $\mathrm{Tl}^{+}$, їх зберіганням, використанням та утилізацією.

3. Інгібітори холінестераз. У даний час фосфорорганічні сполуки (ФОС) широко використовуються у всьому світі: в хімічній промисловості - як розчинники і пластифікатори, в сільському господарстві - в якості інсектицидів і акарицидів, у фармацевтичній промисловості - як лікарські засоби, в оборонній галузі - як бойові отруйні речовини. В останні два десятиліття у багатьох країнах світу широке застосування ФОС стало однією з причин гострих і хронічних отруєнь (професійних, побутових, суїцидальних і кримінальних) [80-87]. За даними ВОО3, щорічно у світі реєструється 3 млн. людей, які перенесли отруєння ФОС, при цьому для 200000 чоловік отруєння мали летальні наслідки [88, 89]. Крім того, зростання активності міжнародного тероризму підвищує ризик застосування як відомих фосфорорганічних отруйних речовин, так і нових сполук 3 невідомою хімічною структурою, що вимагає екстреної медичної допомоги, точної діагностики, ефективного лікування і прогнозу наслідків інтоксикацій, а також наукових розробок стратегії ефективного захисту здоров'я людей у випадку застосування ФОС [90-93].

Про масштаби загрози тероризму свідчать випадки отруєнь у містах Мацумото (1994), Токіо (1995), Аммані (1997), НьюЙорку (2001), Москві (1997, 2002, 2003) та ін. В останні десятиліття масовий тероризм переріс у міжнародний. Відомі транснаціональні терористичні угрупування, зокрема «Аум Сінрікьо», «Аль-Каїда» й ін., які мають можливість використовувати будь-які способи масового тероризму для знищення людей, тварин, рослинності, матеріальних цінностей [94], а також терористичні акти окремих кримінальних елементів або спецслужб, зокрема в Солсбері (2018) і Тюмені (2020), з невідомими високотоксичними ФОС, наприклад такими як «Новачок».

Серед фосфорорганічних речовин, здатних швидко викликати гостре отруєння 3 летальним результатом, важливе місце посідають блокатори холінестераз (XЕ), зокрема бойові отруйні речовини - зарин, зоман, табун, V-гази, які можуть потрапити до рук терористів шляхом захоплення об'єктів їхнього зберігання або пошкоджень місць зберігання в результаті збройних дій або при утилізації. Крім того, не виключено використання хімічних речовин іншого призначення (промислові хімічні речовини, пестициди та ін.), які більш доступні. Використання сучасних знань, підготовки, технічного забезпечення і фінансових можливостей суб'єкта, який виступає в якості терориста, не виключає синтезу токсичних речовин у підпільних лабораторіях [94, 95].

До речовин, що володіють антихолінестеразною дією, крім ФОС, відносяться речовини нарізноманітнішої хімічної будови і з дуже різними біологічними властивостями. Понад половину антихолінестеразних речовин (в залежності від тієї функціональної хімічної групи, яка визначає їх антихолінестеразні властивості) поділяють на 4 основні групи: четвертинні амонієві сполуки, складні ефіри карбамінової кислоти (уретан і карбамати), фосфорорганічні речовини та інші. Досить виразною антихолінестеразною дією можуть володіти й інші речовини, наприклад наркотики, стрихнін, речовини кураророподібної і місцево подразнюючої дії, азотистий іприт та інші. Однак цю дію вони виявляють тільки в порівняно високих концентраціях, в зв'язку з чим здатність пригнічувати активність XE не $€$ визначальною щодо механізмів біологічної дії [96-99]. 
Більшість антихолінестеразних сполук мають високу фізіологічну активність, у зв'язку з чим багато з них (езерин, прозерин, фосфакол, армін, піридостигмін і ін.) застосувуються в медичній практиці для лікування захворювань, а деякі знаходяться на озброєнні як високотоксичні бойові отруйні нейропаралітичні речовини (табун, зарин, зоман, V-гази). В даний час фосфорорганічні пестициди і похідні карбамінової кислоти становлять значну частину асортименту препаратів, які широко використовуються в сільському і лісовому господарстві, в тваринництві як активні інсектициди і акарициди [98] i тому широко доступні для населення.

Механізм реакцій ФОС 3 холінестеразою, холінорецепторами (ХР), залежність їхньої дії на організм від структури детально висвітлено у багатьох роботах Aldridg W.N. (1950, 1981), Brain O. (1964, 1976), Fukuto T. (1972), Casida J.E. (1973), Голіков C.H. (1970, 1972, 1973), Eto M. (1974), Narahashi T. (1976) та інших, і узагальнені в публікаціях [98, 100-104]. Доведено, що при взаємодії з ФОС холінестеразний центр міцно зв'язується із залишком фосфорної кислоти, що призводить до утворення надзвичайно стійкого до гідролізу фосфорильованого ферменту, нездатного реагувати з молекулами ацетилхоліну (AX) через втрату своєї основної каталітичної функції. В результаті інактивації XЕ відбувається накопичення $\mathrm{AX}$ в холінергічних синапсах, гіперстимуляція рецепторів, порушення проходження і блокада проведення нервового імпульсу через синаптичну мембрану, що веде до порушення діяльності центральної і периферичної нервової системи, інших життєво важливих органів, згодом до летальності. Інгібування холінестераз є головним у механізмі токсичної дії ФОС. Однак, оскільки XЕ і ХР мають у своїй будові багато загального, то в механізмі дії антихолінестеразних сполук певне значення може мати їх взаємодія не тільки 3 ферментом, а й з ХР. При цьому деякі ФОС (фосфакол, ДФФ, паратіон, армін та ін.) можуть проявляти як збудливу, так i блокуючу дію на ХР [98, 105-107].

Серед ФОС є речовини з різним ступенем токсичності. По токсичності ФОС поділяють на:

1. Сильнодіючі токсичні речовини $\left(\mathrm{LD}_{50}-10-50\right.$ мг/кг) - тиофос, меркапто- фос, метилетилтиофос.

2. Високотоксичні речовини $\left(\mathrm{LD}_{50}-\right.$ 50-200 мг/кг) - метилмеркаптофос, фосфамід, ДДВФ, базудин, антіо, цидеал, фталофос, бензофосфат.

3. Помірно токсичні речовини $\left(\mathrm{LD}_{50}-\right.$ 200-1000 мг/кг) - хлорофос, метилнітрофос, карбофос, трихлорметафос-3, сайфoc.

4. Малотоксичні речовини $\left(\mathrm{LD}_{50}-\right.$ більше 1000 мг/кг) - вінілфосфат, бромофос, абат, цианокс, валексон, демуфос.

В окрему групу виділяють бойові отруйні речовини $\left(\mathrm{LD}_{50}\right.$ менше $\left.10 \mathrm{Mг} / \mathrm{кг}\right)-$ зарин, зоман, VX [93, 108-110].

Залежно від дози, що надійшла до організму, ознаки інтоксикації ФОС можуть розвиватися відразу або через кілька годин. Для більш ліпофільних сполук, які вимагають метаболічної активації, симптоми інтоксикації розвиваються повільно і можуть зберігатися кілька діб. Залежно від структури речовини, швидкості та спрямованості метаболізму може змінюватися вираженість тих чи інших порушень з боку центральної нервової системи.

При гострій інтоксикації ФОС симптоми холінергічної кризи включають: мускаринові ефекти (нудота, блювання, діарея, абдомінальні судоми, нетримання сечі, міоз, бронхорея, бронхоконстрикція, дихальна недостатність, слюно- і сльозотеча, гіпотонія, брадикардія, аритмія); нікотинові ефекти (м'язова слабкість, тремор, парез діафрагми, гіпертензія, тахікардія, мідріаз); зміни центральної нервової системи (стурбованість, збуджений стан, головний біль, запаморочення, атаксія, втрата пам'яті, судоми, коматозний стан).

Перші ознаки холінергічних симптомів з'являються тоді, коли активність ацетилхолінестерази (AXE) в крові знижується на $50 \%$, пригнічення активності ферменту на $75 \%$ призводить до тяжкого ступеня інтоксикації та є індикатором небезпеки, що вимагає прийняття термінових заходів щодо усунення впливу речовини $[87,98]$.

Загальним в дії багатьох ФОП як при гострому, так і хронічному впливі $є$ залежність "доза-ефект". Зі збільшенням дози введеної речовини посилюється ефект незалежно від шляху надходження до організму. Ступінь вираженості інгібування при введенні однакових доз залежить від 
видової та індивідуальної чутливості організму. Речовини з високим антихолінестеразним ефектом in vitro виявляють токсичну дію в перші години після введення речовини. Для речовин з менш вираженими антихолінестеразними властивостями in vitro, а також речовини, які вимагають попередньої активації (тіонофосфати), токсична дія і антихолінестеразний ефект проявляються в більш пізні терміни.

Оскільки ФОС вибірково блокують ХЕ в усіх холінергічних структурах (М- і Нхолінорецептивні системи), до патологічного процесу можуть залучатися практично всі фізіологічні системи та органи. При цьому зміни діяльності центральної та периферичної нервової системи, а також як наслідок - порушення дихання та серцевої діяльності мають вирішальний вплив на наслідки отруєння.

Слід зазначити, що однією з ранніх ознак впливу ФОС на організм можуть бути зміни вищої нервової діяльності. Такі отрути як зарин, зоман, дихлофос, паратіон й ін. при введенні навіть у невеликих дозах - від 0,1 до 0,3 $\mathrm{LD}_{50}$ впливають на регулярність і відтворення мимовільних вроджених реакцій (сприйняття слухових і зорових стимулів, споживання води та їжі) [111]. Розвиток клоніко-тонічних судом при гострому отруєнні ФОС (фосфакол, ДФФ, зарин, табун, паратіон, ДДВФ, хостаквік і ін.) може свідчити про залучення до патологічного процесу спинного мозку. Слід також зазначити, що ФОС з вираженою антихолінестеразною дією $\left(\mathrm{I} 50=1 \times 10^{-7}-1 \times 10^{-9} \mathrm{M}\right) \in$ сильними міотиками. Міоз може слугувати критерієм тяжкості стану хворих. При важких отруєннях "точкові" зіниці зберігаються довго, реакція на світло відсутня, відзначається вертикальний і горизонтальний ністагм [108].

Нехолінергічні механізми проявляються в основному при повторних надходженнях до організму невеликих доз препаратів, нездатних викликати виражені холінергічні реакції, і відіграють зазвичай більшу роль в дії менш токсичних ФОС, до яких відносяться багато пестицидів [98].

Низка ФОС різної структури - фосфати, фосфонати, амідофосфати здатні викликати віддалену нейротоксичну дію (ВНД). Цей ефект проявляється після латентного періоду (14-21 день, а іноді через кілька років після перенесеного гострого отруєння) i характеризується виникненням атаксії, м'язової слабкості, парезів і паралічів кінцівок, демієлінізації волокон провідних шляхів спинного мозку і периферичних нервів. Класичними ФОС, які володіють ВНД є тріортокрезилфосфат (ТОКФ) і лептофос. Нині описано понад 40 тисяч випадків виникнення парезів i паралічів у людей через дію ФОС (ТОКФ, міпафокс, лептофос, хлорпірифос, хлорофос і ін.) [112-116].

Механізм ВНД ФОС остаточно не з'ясований. Важливою патогенетичною ланкою порушень вважають фосфорилювання білка, який відноситься до карбоксилестераз і названий нейротоксичною естеразою (EC 3.1.1.5, НTE) [112, 113, 117, 118]. Віддалені нейропатії виникають лише в разі впливу таких ФОС, які пригнічують НТЕ на 70-80\%, причому розвиток ВНД пов'язаний не тільки з пригніченням НТЕ, але і з подальшим iї "старінням" [119]. Останнім часом тривають дослідження структури НТЕ та іiі функціональної ролі. Виявлено деяку гомологію НТЕ з Са-незалежною фосфоліпазою А. Показано, що для ФОС, які викликають ВНД, інгібування НТЕ супроводжується порушенням гомеостазу мембранних фосфоліпідів, що призводить до пошкоджень аксонального транспорту [118]. Обговорюється роль НТЕ в гідролізі лізофосфатидилхоліну та участі ліпаз у детоксикації деяких ФОС [120].

Цілком ймовірно, що до речовин, які чинять ВНД, можна віднести і хімічну речовину «Новачок», яка в останні роки була використана як засіб отруєння людей.

Згідно з даними доступними в Інтернеті, отруйна речовина «Новачок» (https://m.pikabu.ru/ story/otravlyayushchee_veshchestvo_quotnovichokquot_5778177) за своєю структурою і механізмом дії відноситься до фосфорорганічних речовин нервово-паралітичної дії, а за токсичністю в 5-8 разів перевершує відому бойову отруйну речовину VX. За механізмом дії серія отруйних речовин під назвою «Новачок» - це незворотні інгібітори ацетилхолінестерази. Про симптоми отруєння «Новачками» відомо мало, вважається що клінічна картина отруєння така ж, як і при ураженні звичайними нервово-паралітичними бойовими 
отруйними речовинами (БОР) - зарин, зоман, VX та ін. Однак існують і відмінності, які полягають в тому, що ураження цими речовинами були фактично невиліковними. Люди, які свого часу зазнали впливу цієї речовини, ставали непрацездатними, тобто інвалідами внаслідок розвитку паралічів і пошкодження внутрішніх органів. Ці явища виникають відтерміновано після отруєння деякими фосфорорганічними речовинами, вони характерні для ВНД і, на жаль, практично не лікуються відомими засобами.

Виходячи з механізму ВНД ФОС, поряд з загальновизнаними способами лікування і антидотною терапією (реактиваторами периферичної та центральної дії) [91, 108], у ранні терміни отруєння доцільно застосовувати гемокарбоперфузію і імунодепресанти 3 метою попередження ускладнень виникнення парезів і паралічів [121-124] .

3 огляду на високу токсичність, велику поширеність і доступність ФОС, існуе високий ризик використання їх кримінальними особами 3 метою отруєння людей, тварин, нанесення шкоди навко- лишньому середовищу. У зв'язку з цим, необхідно підвищити відповідальність осіб, зайнятих зберіганням, застосуванням, транспортуванням та утилізацією цих небезпечних речовин. Особливо жорсткого контролю потребують такі високотоксичні речовини як метилнітрофос, метафос, тіофос, метилмеркаптофос, метилетилтіофос, октаметил, трикрезилфосфат, а також БОР.

Беручи до уваги тяжкість уражень при гострих інтоксикаціях, високу інвалідизацію, можливість летальних випадків, необхідно удосконалювати комплексний підхід до швидкої і надійної ідентифікації отруйних речовин, лікування гострих отруєнь, розробити стратегію багаторівневого захисту населення і об'єктів навколишнього середовища в разі використання ФОС не за призначенням. Особливої актуальності набуває підготовка медичної служби до швидкого реагування на терористичні акти з використанням цих отруйних речовин, діагностика, евакуація та надання першої медичної допомоги.

\section{ЛІТЕРАТУРА}

1. Проект Закону України «Про хімічну безпеку» та проекти технічних регламентів як підзаконні акти. Мультимедійні матеріали. URL: https://mepr.gov.ua/ news/36207.html.

2. Азаров ДС, Грищук ВК, Савченко АВ та ін. Науково-практичний коментар Кримінального кодексу України. Джужа $\mathrm{OM}$, Савченко $\mathrm{AB}$, Чернєй $\mathrm{BB}$, редактори. 2-ге вид., перероб. і допов. Київ: Юрінком Інтер; 2018, 1104 с.

3. Максимчук IM. Отруйні речовини як елемент криміналістичної характеристики окремих кримінальних правопорушень. Науковий вісник публічного та приватного права. Збірник наукових праць. К.: Науково-дослідний інститут публічного права; 2019; 4(1): 32 с.

4. Про імплементацію Угоди про асоціацію між Україною, 3 однієї сторони, та Європейським Союзом, Євро-пейським Співтовариством 3 атомної енергії і їхніми державами-членами, 3 іншої сторони: Розпорядження Кабінету Міністрів України від 17.09.2014 № 847-р. URL: https://zakon5.rada.gov.ua/laws/show/847-2014.

5. Про виконання Угоди про асоціацію між Україною, 3 однієї сторони, та Європейським Союзом, Європейським співтовариством з атомної енергії і їхніми державами-членами, з іншої сторони: Розпорядження Кабінету Міністрів України від 25.10.2017 № 1106. URL: https://zakon.rada.gov.ua/laws/show/1106-2017.

6. Про ратифікацію Угоди про асоціацію між Україною, 3 однієї сторони, та Європейським Союзом, Європейським співтовариством з атомної енергії і їхніми державами-членами, 3 іншої сторони: Закон України від 16.09.2014 № 1678-VII. URL: https://zakon.rada.gov.ua/ laws/ show/1678-18.
7. Про визнання такими, що втратили чинність, деяких постанов Кабінету Міністрів України: Постанова Кабінету Міністрів України від 03.09.2014 № 405. URL: https://zakon.rada.gov.ua/ laws/show/405-2014.

8. Про затвердження Порядку одержання дозволу на виробництво, зберігання, транспортування, використання, захоронення, знищення та утилізацію отруйних речовин, у тому числі продуктів біотехнології та інших біологічних агентів: Постанова Кабінету Міністрів України від 20.06.1995 № 440. URL: https://zakon.rada.gov.ua/laws/show/440-95.

9. Moshiri M, Hamid F, Etemad L. Ricin Toxicity: Clinical and Molecular Aspects. Reports of Biochemistry \& Molecular Biology. 2016; 4(2): 60-5.

10. Супоницкий МВ. Распознавание поражений рицином. Прикладная токсикология. 2013; 9(1): 44-9.

11. Bigalke H, Rummel A. Medical aspects of toxin weapons. Toxicol. 2005; 214: 210-20.

12. Audi J, Belson M, Patel M, et al. Ricin poisoning. A comprehensive review. JAMA. 2005; 294(18): 2343-3251.

13. Griffith GD, Phillips GJ, Holley J. Inhalation toxicology of ricin preparations: animal models, prophylactic and therapeutic approaches to protection. Inhal. Toxicol. 2007; 19: 873-87.

14. Wannemacher RW, Anderson JB, Inhalation ricin aerosol procedures, toxicology and therapy. Inhal. Toxicol. 2006; 42: $973-80$

15. Lord MJ, Jolliffe NA, Marsden CJ, et al. Ricin Mechanisms of cytotoxicity. Toxicol. Rev. 2003; 22: 53-64.

16. Sehgal P, Khan M, Kumar O, Vijayaraghavan R. Purification, characterization and toxicity profile of ricin 
isoforms from castor beans. Food and chemical toxicology: an international journal published for the British Industrial Biological Research Association. 2010; 48(11): 3171-6.

17. Bradberry S. Ricin and abrin. Medicine. 2012; 40(2): 80-1.

18. Rana M, Dhamija H, Prashar B, Sharma S. Ricinus communis L. International Journal of Pharm Tech Research. 2012; 4(4): 1706-11.

19. Wilhelmsen CL, Pitt ML. Lesions of acute inhaled lethal ricin intoxication in rhesus monkeys. Veterinary pathology. 1996; 33(3): 296-302.

20. Christiansen VJ, Hsu CH, Dormer KJ, Robinson CP. The cardiovascular effects of ricin in rabbits. Pharmacology \& toxicology. 1994; 74(3): 148-52.

21. Coopman V, De Leeuw M, Cordonnier J, Jacobs W. Suicidal death after injection of a castor bean extract (Ricinus communis L.). Forensic Sci Int. 2009; 189(1-3): 13-20.

22. Targosz D, Winnik L, Szkolnicka B. Suicidal poisoning with castor bean (Ricinus communis) extract injected subcutaneously - case report. J. Toxicol Clin Toxicol. 2002; 40: 398.

23. Doan LG. Ricin mechanism of toxicity, clinical manifestations, and vaccine development. A review. J. Toxicol Clin Toxicol. 2004; 42(2): 201-8.

24. Bradberry SM, Dickers KJ, Rice P, Griffits GD, Vale JA. Ricin poisoning. Toxicological reviews. 2003; 22(1): 65-70.

25. Balali-Mood M, Moshiri M. Problems of Clinical Diagnosis and Management of a Deliberate Biological Born Disease. J Bioterror Biodef. 2015; 6: 113.

26. Антонов НС. Химическое оружие на рубеже двух столетий. М.: A\O Издательская группа «Прогресс»; 1994.

27. Franz D, Jaax N. Ricin toxin. Medical aspects of chemical and Biological Warfare. Washington; 1997. 631-642.

28. Бова АА, Горохов СС. Военная токсикология и токсикология экстремальных ситуаций. Минск; 2005. 224-240.

29. Crompton R, Gall D. Georgi Markov - death in a pellet. The Medico-legal journal. 1980; 48(2): 51-62.

30. Worbs S, Kohler K, Pauly D, Avondet MA, Schaer M, Dorner $\mathrm{MB}$, et al. Ricinus communis Intoxications in Human and and Veterinary Medicine-A Summary of Real Cases. Toxins (Basel). 2011; 3(10): 1332-72.

31. Johnson RC, Lemire SW, Woolfitt AR, Ospina M, Preston $\mathrm{KP}$, Olson CT, et al. Quantification of ricinine in rat and human urine: a biomarker for ricin exposure. J Anal Toxicol. 2005; 29(3): 149-55.

32. Stewart CC. Weapons of Mass Casualties and Terrorism Response Handbook. London: Jones \& Bartlett; 2005.

33. Zhao Z, Worthylake D, LeCour L, Jr., Maresh GA, Pincus $\mathrm{SH}$. Crystal structure and computational modeling of the fab fragment from a protective antiricin monoclonal antibody. PloS one 2012; 7(12): e52613.

34. Moshiri M, Etemad L, Balali-Mood M. The Biowarfare Agent Ricin. Biological Toxins and Bioterrorism Series: Toxinology, Springer; 2014; 1: 43-59.

35. Wu F, Fan S, Martiniuk F, Pincus S, Muller S, Kohler H, et al. Protective effects of anti-ricin A-chain antibodies delivered intracellularly against ricin-induced cytotoxicity. World journal of biological chemistry. 2010; 1(5): 188-95.

36. Pincus SH, Smallshaw JE, Song K, Berry J, Vitetta ES. Passive and active vaccination strategies to prevent ricin poisoning. Toxins. 2011; 3(9): 1163-84.

37. Toxicological review of thallium and compounds. U.S. Environmental Protection Agency. Washington. D.C. 2009. EPA/635/R-08/001F.www.epa.gov/iris.
38. Gresham C, Vearrier D. Thallium Toxicity. Medscape. com. 2018 Feb. 19.

39. Завалий ЛБ, Петриков СС, Симонова АЮ, Поцхверия ММ, Остапенко ЮН. Характеристика неврологических расстройств у пациентов с острым отравлением таллием. Consilium Medicum. 2019; 21(2): 24-30.

40. Osorio-Rico L, Santamaria A, Galván-Arzate S. Thallium Toxicity: General Issues, Neurological Symptoms, and Neurotoxic Mechanisms. Adv Neurobiol. 2017; 18: 345353. doi: 10.1007/978-3-319-60189-2_17.

41. Galván-Arzate S, Santamaría A. Thallium toxicity. Toxicol Lett. 1998; 99(1): 1-13.

42. Di Candia D, Muccino E, Battistini A, Boracchi M, Gentile G, Zoja R. Thallium toxicity due to adulterer infusion with thallium sulfate in eight members belonging to the same family nucleus: Autopsy findings and ICP-MS analysis (inductively coupled plasma mass spectrometry) in a triple homicide. Leg Med (Tokyo). 2020; 42: 101661. doi: 10.1016/j.legalmed.2019.101661.

43. Sojakova M, Zigrai M, Karaman A, Plackova S, Klepancova P, Hrusovsky S. Thallium intoxication. Case Report. Neuro Endocrinol. Lett. 2015; 36(4): 311-31.

44. Sharma AN, Nelson LS, Hoffman RS. Cerebrospinal fluid analysis in fatal thallium poisoning: evidence for delayed distribution into central nervous system. Am. J. Forensic Med. Pathol. 2004; 25: 156-8.

45. Aoyama H, Yoshida M, Yamamura Y. Acute poisoning by intentional ingestion of thallous malonate. Hum Toxicol. 1986; 5(6): 389-92.

46. Riyaz R, Pandalai SL, Schwartz M, Kazzi ZN. A fatal case of thallium toxicity: challenges in management. J Med Toxicol. 2013; 9(1): 75-8. doi: 10.1007/s13181-012-0251-1.

47. Yang G, Li C, Long Y, et al. Hair loss evidence to thallium poisoning. Case Rep Emerg Med. 2018.

48. Балан ГМ, Богомол АГ, Жмінько ПГ, Бубало НМ, Бубало ВО, Кудрявцева АГ, та ін. Гострі пероральні та інгаляційні отруєння талієм і їх віддалені наслідки. 2020; 1: 79-90.

49. Locatelli C, Petrolini V. Long-lasting polyneuropathy and psychiatric disorders in thallium poisoning. Study of six cases. Toxicology Letters. 2003; 144(1): 72-4.

50. Балан ГМ, Богомол АГ, Кравчук ОП, Жмінько ПГ, Кудрявцева АГ. Комплексна терапія гострих отруєнь сполуками талію (Огляд літератури та дані власних досліджень). 2020; 2: 40-7.

51. Чухловина МЛ. Медико-гигиенические аспекты нейротоксичности таллия. Гиг. и санитария. 1999; 4: 38-40.

52. Osorio-Rico L, Villeda-Hernandez J, Santamaria A, Konigsberg M. The N-Methyl-d-Aspartate Receptor Antagonist MK-801 Prevents Thallium-Induced Behavioral and Biochemical Alterations in the Rat Brain. International J. of Toxicology. 2015; 34(6): 505-13 DOI: $10.1177 / 1091581815603936$.

53. Ливанов ГА, Остапенко ЮН, Шестова ГВ, и др. Значение ранней диагностики острых тяжелых отравлений соединениями таллия на начальных стадиях интоксикации. Токсикол. вестник. 2011; 5: 1-8.

54. Tsai YT, Huang CC, Kuo HC, et al. Central nervous system effects in acute thallium poisoning. Neurotoxicology. 2006; 27: 291-5.

55. Misra UK, Kalita J. Yadav, Ranjan P. Thallium poisoning: emphasis on early diagnosis and response to haemodialysis. Postgrad Med. J. first published. 2003; 2: 48-50. WWW.postgradmed j com. 
56. Kuroda H, Mukai Y, Nishiyama S, Takeshita T, Takeshita T, Tateyama M, et al. Tardily accelerated neurologic deterioration in two-step thallium intoxication. J. Clin Neurosci. 2016; 34: 234-6. DOI: 10.1016/j.jocn.2016.09.003. Epub 2016 Sep. 28.

57. Остапенко ЮН, Ливанов ГА, Шестова ГВ, Рутковский ГВ, и др. Отравление соединениями таллия (клиника, диагностика, лечение) Метод. рекомендации. М; 2010. $30 \mathrm{c}$.

58. Sha S, Kumar R. Thallium poisoning. Presenting as Paresthesias, Paresis, Psychosis and Pain in Abdomen. JAPI. 2006; 54: 53-55.

59. Centers for Disease Control and Prevention (CDC) Thallium poisoning from eating contaminated cake - Iraq, 2008. MMWR Morb Mortal Wkly Rep. 2008; 57: 1015-8.

60. Almassri I, Sekkarie M. Cases of thallium intoxication in Syria: A diagnostic and a therapeutic challenge. Avicenna J Med. 2018; 8(3): 78-81.

61. Ливанов ГА, Шестова ГВ, Суходолова ГН, Батоцыренов БВ, и др. Клиника, диагностика и лечение острых тяжёлых отравлений соединениями таллия. Скорая медицинская помощь. 2019; 3: 9-15.

62. Kuo HC, Huang CC, Tsai YT, et al. Acute painful neuropathy in thallium poisoning. Neurology. 2005; 65: 302-4.

63. Ammendola A, Ammendola E, Argenzio F, et al. Clinical and electrodiagnostic Follow-up of an adolescent poisoned with thallium. Neurol Sci. 2007; 28: 205-8.

64. Поддубный Н. Отравление века (2012-01-24). https://www.webcitation.org/6DV9upYYYur.

65. Поддубный Н. Уничтожить оборотня. - Киев. - 2012.

66. Гужва И, Ильченко А. Двенадцать главных отравлений Украины https://www.webcitation.org/6DV9wfjiRurl. Сегодня. иа. 2009-07-09.

67. «Отруйна школа». Документальний серіал (випуск № 205 від 16 червня 2012 року, НТВ).

68. Остапенко ЮН, Ливанов ГА, Шестова ГВ, Рутковский ГВ. Отравления соединениями таллия (клиника, диагностика и лечение). Методические рекомендации. М; 2010. $30 \mathrm{c}$.

69. Yumoto T, Tsukahara K, Naito H, Iida A, Nakao A. A Successfully Treated Case of Criminal Thallium Poisoning. J Clin Diagn Res. 2017 Apr; 11(4): OD01-OD02. doi: 10.7860/JCDR/2017/24286.9494.

70. Al Hammouri F, Darwazeh G, Said A, Ghosh RA. Acute thallium poisoning: series of ten cases. J Med Toxicol. 2011 Dec; 7(4): 306-11. doi:10.1007/s13181-011-0165-3.

71. Yu V, Juhász M, Chiang A, Atanaskova Mesinkovska N. Alopecia and Associated Toxic Agents: A Systematic Review. Skin Appendage Disord. 2018 Oct; 4(4): 245-60. doi: $10.1159 / 000485749$.

72. Jiang Y, Xia W, Zhang B, Pan X, Liu W, Jin S, et al. Predictors of thallium exposure and its relation with preterm birth. Environ Pollut. 2018 Feb; 233: 971-976. doi: 10.1016/j.envpol.2017.09.080.

73. Sun TW, Xu QY, Zhang XJ, Wu Q, Liu ZS, Kan QC, et al. Management of thallium poisoning in patients with delayed hospital admission. Clin. Toxicol. (Phila). 2012; 50(1): 65-9.

74. Yang Yongsheng, Faustino PJ, et al. Quantitative determination of thallium binding to ferric hexacyanoferrate: Prussian blue. International J. of Pharmaceutics. 2008; 27: 291-5.

75. Yu-Tai Tsai, Chin-Chang Huang, et al. Central nervous system effects in acute thallium poisoning. Neuro Noxicjlogy. 2006; 27: 291-5.
76. Guodong Lin PhD, Luo Yuan PhD, Lili Bai BM, Yanging Liu BM, Yongan Wang PhD, Zewu Qiu Ph.D. Successful treatment of a patient with severe thallium poisoning in a coma using Prussian blue and plasma exchange. Medicine (Baltimore). 2019 Feb; 98(8): e 14629. DOI: 10.1097/MD.0000000000014629. PMCID: PMC 6407929. PMID 30813198.

77. Osorio-Rico L, Santamaria A, Galván-Arzate S. Thallium Toxicity: General Issues, Neurological Symptoms, and Neurotoxic Mechanisms. Adv Neurobiol. 2017; 18: 34553. doi: 10.1007/978-3-319-60189-2 17.

78. Ghaderi A, Vahdati-Mashhadian N, Oghabian Z, et al. DARU journal of Pharmaceutical Sciences. 2015; 23: 39.

79. Questel F, Dugarin J, Dally S. Thallium-contaminated heroin. Ann intern Med. 1996; 124 (6): 616.

80. Rees HG. Organophosphates, sheep dip and ill health in farmers. Hum. and Exp. Toxicol. 1998; 17(9): 487.

81. Karalliedde L, Senanayake N. Organophosphorous insecticide poisoning. J. Int. Fed. Clin. Chem. 1999; 11: 1-9.

82. Vucinic S, Joksovic D, Todorovic V. Acute organophosphate insecticide poisoning; Antidotes and intensive care management J. Clin. Toxicol. 2003; 41(4): 444-5.

83. Валевский ВС, Шинкаренко НД, Дубовская НГ, Борисова ИС. К диагностике нейропатий, обусловленных токсическим воздействием фосфорорганических соединений, обладающих отдаленной нейротоксичностью. Современ. пробл. токсикол. 2003; 2: 77-9.

84. Aardema H, Meertens JHJM, Ligtenberg JJM, PetersPolman OM, Tulleken JE, Zijlstra JG. Organophosphorus pesticide poisoning: cases and developments. Netherlands J Med. 2008; 66(4): 149-53.

85. Corriols M, Marin L, Berroteran J. Incidence of acute pesticide poisoning in Nicaragua: A public health concern. Occup. and Environ. Med. 2009; 66(3): 205-10.

86. Балан ГМ, Харченко ОА, Лепешкин ИВ, и др. Острое групповое отравление виноградарей баковой смесью пестицидов. Материалы XV съезда гигиенистов Украины; 2012 г. сент. 20-21; Львов. 2012, С. 408-9.

87. Харченко ОА, Балан ГМ, Бубало НН. Острые отравления фосфорорганическими соединениями: основные клинические синдромы и механизмы их формирования (обзор литературы и данные собственных исследований). Современные проблемы токсикологии пищевой и химической безопасности. 2014; 5(68): 14-28.

88. Díaz-Resendiz KJG, Toledo-Ibarra GA, Girón-Pérez MI. Modulation of Immune Response by Organophosphorus Pesticides: Fishes as a Potential Model in Immunotoxicology. Hindawi Publishing Corporation. Journal of Immunology Research. 2015; 10 p.

89. Биомаркеры и оценка риска: концепции и принципы (Гигиенические критерии состояния окружающей среды; 155). Совместное издание Программы ООН по окружающей среде, Международной организации труда и Всемирной организации здравоохранения. Всемирная организация здравоохранения, Женева. 1996; 96 c.

90. Забродский ПФ. Иммунотоксикология фосфорорганических соединений. Саратов. Издательство «Саратовский источник»; 2016, 289 с.

91. Устінова ЛА, Серединська НМ, Курділь НВ. Токсиканти антихолінестеразної дії: механізм дії, клінічні ознаки та актуальні питання забезпечення засобами антидотної терапії. Сучасні проблеми токсикології, харчової та хімічної безпеки. 2017; 3(79): 73-82. 
92. Boltneva NP, Rudakova EV, Sigolaeva LV, Makhaeva GF. Esterase Status of Various Species in Assessment of Exposure to Organophosphorus Compounds Toxicological Problems. Dishovsky C, Radenkova-Saeva J, editors. Bulgarian Toxicological Society. Military Publishing House; Sofia, Bulgaria. 2014, P. 27-38.

93. Федченко ОВ, Жмінько ПГ. Біомаркери експозиції та ефекту фосфорорганічних сполук (огляд даних літератури та результати власних досліджень). Український журнал сучасних проблем токсикології. 2018; 4: 19-35.

94. Шумейко ВМ. Екологічна токсикологія і тероризм. Біотоксиканти. К.: ЭКОРЕГІО-ЕТХі; 2002. С. 4-27.

95. Weinstein RS, Alibek K. Biological and Chemical Terrorism. Thieme. 2003; 114-47.

96. Голиков СН, Розенгард ВИ. Холинэстеразы и антихолинэстеразные вещества. Л.: Медицина; 1964. 140 с.

97. Голиков СН. Руководство по токсикологии отравляющих веществ. М.: Медицина; 1972. 470 с.

98. Курляндский БА, Филов ВА, Каган ЮС, Кокшарева НВ, Жминько ПГ. Блокаторы холинэстеразы. Общая токсикология. М.: Медицина; 2002. С. 176-236.

99. Карбаматные пестициды: общее введение. Гигиенические критерии состояния окружающей среды. Международная программа по химической безопасности; 64. Материалы ВОЗ. Женева. М.: Медицина. 1991. 126 с.

100. Каган ЮС. Токсикология фосфорорганических пестицидов. М.: Медицина; 1977. С. 48-73.

101. Maxwell DM, Lenz DE, Ballantyne B, Marrs TC. Structure-activity relationships and anticholinesterase activity. Clinical and Experimental Toxicology of Organophosphates and Carbamates. Oxford: ButterwordHeinemann Ltd; 1992. P. 47-58.

102. Бресткина АП, Розенгарт ВИ, Шерстобитов ОЕ. Избирательная токсичность фосфорорганических инсектоакарицидов. Сравнительно-биохимические аспекты. Л.: Наука, Ленинградское отд.; 1978. 173 с.

103. Ballantyne B, Marrs TC, Aldridge WN. Clinical and Experimental Toxicology of Organophosphates and Carbamates. Oxford: Butterword-Heinemann Ltd; 1992. $641 \mathrm{p}$.

104. Фосфорорганические инсектициды: общее введение. Гигиенические критерии состояния окружающей среды; 63. Материалы ВОЗ. Женева. М.: Медицина. 1990. $167 \mathrm{c}$.

105. Голиков СН, Кузнецов СГ. Современные представления о природе холинорецептора. Вестник АМН СССР. 1970; 2: 67-85.

106. Аничков СВ. Избирательное действие медиаторных средств. Л.: Медицина; 1974. 295 с.

107. Прозоровский ВБ, Саватеев НВ. Неантихолин-эстеразные механизмы действия антихолинэстеразных веществ. М.: Медицина, 1976. 160 с.

108. Лужников ЕА. Острые отравления: Руководство для врачей. М.: Медицина; 2000. 434 с.

109. Куценко СА. Основы токсикологии: Научно-методическое издание. СПб.: ООО Изд. «Фолиант»; 2004. 720 с.

110. Rosenberg YJ. A pretreatment or post exposure treatment for exposure to a toxic substance by pulmonary delivery (inhaler) of a bioscavenger. PCT Int. Appl. (WO 2005000195 A2). 2005; 6(1): 22.
111. Ballantyne B, Marrs TC, D’Mello DG. Neurobehavioural toxicology of anticholinesterases. Clinical and experimental toxicology of organophosphates and carbamates. Oxford: Butterworth-Heinemann Ltd; 1992. 61-75.

112. Johnson MK. Improved assay of neurotoxic esterase for screening organophosphates for delayed neurotoxicity potential. Arch. Toxicol. 1977; 37: 113-5.

113. Lotti M, Becker CE, Aminoff MY. Organophosphate polyneuropathy: pathogenesis and prevention. Neurology. 1984; 34: 658 .

114. Ballantyne B, Marrs TC, Johnson MK. Molecular events in delayed neuropathy: experimental aspects of neuropathy target esterase. Clinical and Experimental Toxicology of Organophosphates and Carbamates. Oxford: ButterwordHeinemann Ltd; 1992, 90-113.

115. Tkachenko II, Kokshareva NV, Kagan YuS, et al. A study of the delayed neurotoxic effect of a new organophosphorous fungicide 0,0-diphenyl-1-acetoxy-2,2,2-trichlorethylphosphonate (aphos). Communication 1. Clinical manifestations and neurotoxic esterase inhibition. Fresenius Env. Bul. 1992; 1: 571-6.

116. Tkachenko II, Kokshareva NV, Kagan YuS, et al. A study of the delayed neurotoxic effect of a new organophosphorous fungicide 0,0-diphenyl-1-acetoxy-2,2,2-trichlorethylphosphonate (aphos). Communication 2. Electrophysiological and morpholodical investigations. Fresenius Env. Bul. 1993; 2: 131-6.

117. Проданчук НГ, Кокшарева НВ. Достижения в области изучения механизмов действия и прогнозирования отдаленных нейропатий, вызванных фосфорорганическими соединениями. Соврем. пробл. токсикол. 2001; 3: $3-8$.

118. Glynn P. A mechanism for organophosphate-induced delayed neuropathy 42 Congress of the European Societies of Toxicology. Cracow, 2005. Sept 11-14. Paul Glynn. Toxicol. Lett. 2006; 162(1): 94-7.

119. Hayes WJ. Pesticides studied in man. Baltimor, London: Williams and Wilkins; 1982. $672 \mathrm{p}$.

120. Casida JE, Nomura DK, Vose SC, Kazutoshi F. Organophosphate-sensitive lipases modulate brain lysophospholipids, ether lipids and endocannabinoids. Chem. Biol. Interact. 2008; 175: 1-3.

121. Жминько ПГ, Король ВМ, Коляденко ВГ, Проданчук МГ. Способ профилактики осложнений отдаленных нейропатий, вызванных нейропаралитическими фосфорорганическими веществами. Патент на изобретение №38876 А от 15.05.2001 г.

122. Жминько ПГ. Роль иммунной системы в патогенезе отдаленной нейротоксичности некоторых фосфорорганических соединений. Современные проблемы токсикологии. 1999; 4: 18-24.

123. Жмінько ПГ, Лобода ЮІ. Дослідження ефективності циклофосфану в попередженні парезів і паралічів при віддаленій нейротоксичній дії фосфорорганічних речовин. Современные проблемы токсикологии. 2003; 2: $72-3$.

124. Zhminko PG, Kokshareva NV. Delayed Neurotoxicity Induced by Organophosphates: Experimental Correction of Neuropathy. Toxicological Problems. Sofia, Bulgaria: Publishing Hous Irita; 2011, 175-83. 


\title{
К ОБОСНОВАНИЮ ПЕРЕЧНЯ ОПАСНЫХ ВЫСОКОТОКСИЧНЫХ ХИМИЧЕСКИХ ВЕЩЕСТВ, ТРЕБУЮЩИХ ОСОБОГО КОНТРОЛЯ НАД ИХ ОБОРОТОМ, ХРАНЕНИЕМ, ИСПОЛЬЗОВАНИЕМ И УТИЛИЗАЦИЕЙ \\ Часть 1 (рицин, соединения таллия и фосфорорганические соединения)
}

\author{
Н.Г. Проданчук ${ }^{1}$, Г.М. Балан ${ }^{1}$, А.П. Кравчук ${ }^{1}$, П.Г. Жминько ${ }^{1}$, И.Н. Максимчук ${ }^{2}$, Н.П. Чермных ${ }^{1}$ \\ ${ }^{1}$ ДП «Научный центр превентивной токсикологии, пищевой \\ и химической безопасности имени академика Л.И. Медведя МЗ Украины», г. Киев, Украина \\ ${ }^{2}$ Национальная полиция Украины, г. Киев, Украина
}

PЕЗЮМЕ. Цель работы. На основании аналитического обзора литературных данных выделить группу высокотоксичных химических веществ, которые за последние десятилетия чаще всего используются в преднамеренных криминальных и суицидальных инцидентах, диверсионных и террористических актах, оборот, хранение, использование и утилизация которых требуют особенно жесткого контроля правоохранительных органов.

Материалы и методы. Аналитический обзор научных публикаций выполнен с использованием реферативных баз данных научных библиотек Pub Med, Medline и текстовых баз данных научных издательств Elsevier, Pub Med, Central, BMJ group и других VІР-баз данных. Использованы методы системного, сравнительного и контент-анализа.

Результаты и выводы. Проанализированы научные публикации по опасным высокотоксичным химическим веществам, которые за последние 25 лет наиболее часто используются в мире, в частности в преднамеренных криминальных и суицидальных иниидентах, диверсионных и террористических актах и установлено, что к ним относятся преимущественно рицин, соединения таллия, фосфорорганические соединения и боевые отравляющие вещества, мышьяк и его соединения, цианиды и неорганические водорастворимые соединения ртути (сулема, мертиолят натрия), а такэе пестициды паракват и дикват. На основе анализа их токсичности, клинических и морфологических проявлений интоксикации при различных путях поступления в организм обоснована необходимость внесения их в перечень особо опасных химических веществ, оборот которых, хранение, использование и утилизация требуют более жесткого контроля правоохранительных органов. В первой части данной статьи представлены рицин, соединения таллия, фосфорорганические соединения и боевые отравляющие вещества.

Ключевые слова: высокотоксичные опасные химические вещества, рицин, соединения таллия, фосфорорганические соединения, боевые отравляющие вещества.

\section{TO SUBSTANTIATION OF THE LIST OF HAZARDOUS HIGHLY TOXIC CHEMICALS THAT ARE SUBJECT TO SPECIAL CONTROL REGARDING HANDLING, STORAGE, USE AND DISPOSAL \\ Part 1 (ricin, thallium compounds and organophosphorus compounds) \\ M. Prodanchuk ${ }^{1}$, G. Balan ${ }^{1}$, O. Kravchuk ${ }^{1}$, P. Zhminko' I. Maksymchuk ${ }^{2}$, N. Chermnykh ${ }^{1}$ \\ ${ }^{1}$ L.I. Medved's Research Centre of Preventive Toxicology, Food and Chemical Safety, Ministry of Health, Ukraine (State Enterprise), Kyiv, Ukraine \\ ${ }^{2}$ National Police of Ukraine, Kyiv, Ukraine}

ABSTRACT. The Aim of the Research. Based on an analytical review of literature data, to identify a group of highly toxic chemicals which over the past decades are most often used in deliberate criminal and suicidal incidents, sabotage and terrorist act; the traffic, storage, use and disposal of which must be especially carefully monitored by law enforcement agencies.

Materials and Methods. An analytical review of scientific publications was carried out using the abstract databases of scientific libraries Pub Med, Medline and text databases of scientific publishing houses Elsevier, Pub Med, Central, BMJ group as well as other VIP databases. Methods of systemic, comparative, and content analysis were used.

Results and Conclusions. The scientific publications on hazardous highly toxic chemicals, which over the past quarter century are most often used in the world, notably in deliberate criminal and suicidal incidents, sabotage, and terrorist acts, are being analysed. It was found that these chemicals mainly include ricin, thallium compounds, organophosphorus compounds, as well as chemical warfare agents, arsenic and its compounds, cyanides, and inorganic water-soluble mercury compounds (mercury bichloride, sodium merthiolate), as well as paraquat and diquat pesticides. Based on the analysis of their toxicity, clinical and morphological expression of intoxication with various routes of entry into the body, the need to include them in the List of Highly Hazardous Chemicals, whose traffic, storage, use, and disposal require stricter control of law enforcement agencies, is justified. The first part of this article presents ricin, thallium compounds, organophosphorus compounds, and chemical warfare agents.

Key Words: hazardous highly toxic chemicals, ricin, thallium compounds, organophosphorus compounds, chemical warfare agents.

Надійшла до редакції 23.11.2020 